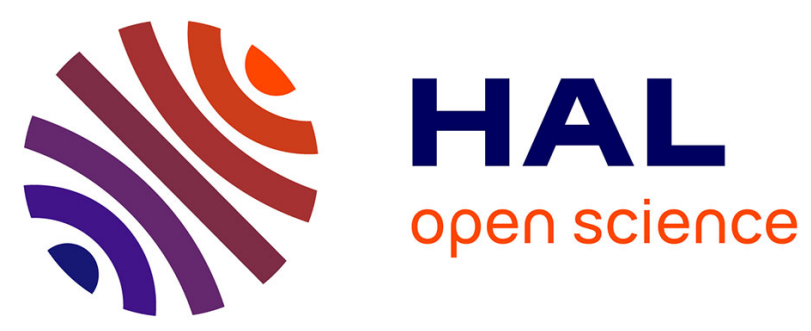

\title{
Pulmonary effects of keratinocyte growth factor in newborn rats exposed to hyperoxia.
}

\author{
Marie-Laure Franco-Montoya, Jacques R. Bourbon, Xavier Durrmeyer, \\ Stephanie Lorotte, Pierre-Henri Jarreau, Christophe Delacourt
}

\section{To cite this version:}

Marie-Laure Franco-Montoya, Jacques R. Bourbon, Xavier Durrmeyer, Stephanie Lorotte, PierreHenri Jarreau, et al.. Pulmonary effects of keratinocyte growth factor in newborn rats exposed to hyperoxia.: KGF effects in hyperoxia-exposed rat pups. American Journal of Physiology - Lung Cellular and Molecular Physiology, 2009, 297 (5), pp.L965-76. 10.1152/ajplung.00136.2009 . inserm00411629

\section{HAL Id: inserm-00411629 https://www.hal.inserm.fr/inserm-00411629}

Submitted on 28 Aug 2010

HAL is a multi-disciplinary open access archive for the deposit and dissemination of scientific research documents, whether they are published or not. The documents may come from teaching and research institutions in France or abroad, or from public or private research centers.
L'archive ouverte pluridisciplinaire HAL, est destinée au dépôt et à la diffusion de documents scientifiques de niveau recherche, publiés ou non, émanant des établissements d'enseignement et de recherche français ou étrangers, des laboratoires publics ou privés. 
Pulmonary effects of keratinocyte growth factor in newborn rats exposed to hyperoxia

Marie-Laure Franco-Montoya ${ }^{1,2,3}$, Jacques R. Bourbon ${ }^{1,2,3}$, Xavier Durrmeyer ${ }^{4}$, Stéphanie Lorotte $^{1,2}$, Pierre-Henri Jarreau ${ }^{3,5,6}$, Christophe Delacourt ${ }^{1,2,3}$

INSERM, Unité 955, IMRB, Équipe 13, Créteil, France ${ }^{1}$,Faculté de Médecine, Université Paris-Val-de-Marne, IFR10, Créteil, France ${ }^{2}$, PremUP, Paris, France, Réanimation Néonatale, Centre Hospitalier Intercommunal, Créteil, France, Service de Médecine Néonatale de Port-Royal, AP-HP, Hôpital Cochin, Paris, France 5 , Université Paris Descartes, Faculté de Médecine, Paris, France ${ }^{6}$

Running head: KGF effects in hyperoxia-exposed rat pups

Corresponding author : Christophe Delacourt Service de Pédiatrie

Centre Hospitalier Intercommunal de Créteil 40 avenue de Verdun

94000 Créteil, France

$\mathrm{Te} 1+33-145175398$

Fax $+33-145175426$

E-mail : christophe.delacourt@chicreteil.fr 


\begin{abstract}
.
Acute lung injury and compromised alveolar development characterize bronchopulmonary dysplasia (BPD) of the premature neonate. High levels of keratinocyte growth factor (KGF), a cell-cell mediator with pleiotrophic lung effects, are associated with low BPD risk. KGF decreases mortality in hyperoxia-exposed newborn rodents, a classical model of injury-induced impaired alveolarization, although the pulmonary mechanisms of this protection are poorly defined. These were explored through in vitro and in vivo approaches in the rat. Hyperoxia decreased by $30 \%$ the rate of wound closure of a monolayer of fetal alveolar epithelial cells, due to cell death, which was overcome by recombinant human KGF $100 \mathrm{ng} / \mathrm{ml}$. In rat pups exposed to $>95 \% \mathrm{O}_{2}$ from birth, increased viability induced by intraperitoneal injection of KGF $(2 \mu \mathrm{g} / \mathrm{g}$ bw) every other day was associated with prevention of neutrophil influx in bronchoalveolar lavage (BAL), prevention of decreases in wholelung DNA content and cell-proliferation rate, partial prevention of apoptosis increase, and markedly increased proportion of SP-B-immunoreactive cells in lung parenchyma. Increased lung anti-oxidant capacity is likely to be due in part to enhanced CEBP $\alpha$ expression. By contrast, KGF neither corrected changes induced by hyperoxia in parameters of lung morphometry that clearly indicated impaired alveolarization, nor had any significant effect on tissue or BAL surfactant phospholipids. These findings evidence KGF alveolar epithelial cell protection, enhancing effects on alveolar repair capacity, and anti-inflammatory effects in the injured neonatal lung that may account, at least in part, for its ability to reduce mortality. They argue in favor of a therapeutic potential of KGF in the injured neonatal lung.
\end{abstract}

Key words: developing lung, alveolar epithelial cell, bronchopulmonary dysplasia, lung inflammation, lung protection 
Despite considerable obstetric and neonatal advances in the care of very low birth weight (VLBW) neonates, bronchopulmonary dysplasia (BPD) continues to occur among 20 to $40 \%$ of survivors, and new ways for combating this disease must be found. Initially described as a fibrotic pulmonary endpoint following severe respiratory distress syndrome, BPD has considerably evolved with changes in the care of VLBW infants and because of survival of lower gestational age infants than in the original description. It is now usually considered to result from interrupted alveolar development exacerbated by life-sustaining but detrimental effects of invasive neonatal practice (4, 15). Newborn animals exposed to hyperoxia, mechanical ventilation, or airway lipopolysaccharide, represent models reproducing the impaired alveolarization observed in premature infants with BPD (1, $41,52)$.

Keratinocyte growth factor (KGF), also known as fibroblast growth factor (FGF) 7, is a critical growth factor in lung development $(10,47)$ and was demonstrated as a protective agent after oxidantinduced lung injury, both in adults and neonates $(3,6,22,38)$. This has potential clinical implication for BPD, since oxidative stress is a component in lung injuries leading to the occurrence of this disease in premature neonates (15). Moreover, previous investigation from our laboratory showed that in premature human neonates, high concentrations of KGF in airways were associated to low risk for BPD (17), whereas mechanical ventilation, another precipitating factor of BPD (15), was reported to down-regulate KGF expression in premature rabbits (19). Last, it was shown that KGF protected premature newborn rats from hyperoxic lethality, but not from hyperoxic inhibition of postnatal alveolar formation and early pulmonary fibrosis (22). The exact mechanisms of its protective effect have not yet been elucidated, however. Although a number of data about pulmonary effects of KGF have been gained from adult studies, they cannot be directly extended to the growing lung, since injuries interfere with developmental events, especially formation of definitive alveoli. Specific effects could therefore be expected from studies in developing animals.

Known effects of KGF on alveolar type II epithelial cells may account for the beneficial effects of this growth factor in hyperoxic exposure. Actually, inducible expression of KGF in mice exposed to 
hyperoxia protected the lung epithelium but not the endothelium from cell death, which is in keeping with the selective expression of KGF receptors on epithelial and not on endothelial cells (43). The well-established stimulatory effect of $\mathrm{KGF}$ on type II cell proliferation $(14,39,53)$ may be insufficient, however, to explain its ability to restore lung tissue integrity in injured lungs (42). Indeed, KGF inhibited the alveolar damage induced by oxygen breathing in mice, despite the fact that its proliferative effect observed in normoxia was abolished under hyperoxia (6). KGF protective effect may be mediated by the enhancement of surfactant synthesis evidenced in adult $(48,50,61)$ as well as fetal (14) alveolar type II cells. Thus far, however, consequences of KGF treatment for surfactant synthesis in the injured neonatal lung remain unknown. In the adult rat lung in vivo, the KGF-induced increase in surfactant protein mRNA per lung was shown to result from type II cell hyperplasia, whereas the mRNA content per cell was slightly diminished (63). Moreover, surfactant homeostasis was unchanged in type II cell hyperplasia (20). Finally, the contribution of an anti-apoptotic effect of KGF to its protective effect is another likely hypothesis $(12,32)$. Reactive oxygen species (ROS) are released into the alveolar space and contribute to alveolar epithelial damage in patients with acute lung injury. It was shown that $\mathrm{H}_{2} \mathrm{O}_{2}$ inhibits alveolar epithelial wound repair in large part by induction of apoptosis, and that apoptosis inhibition can maintain wound repair and cell viability in the face of ROS (24). Consistent with this assumption, $\mathrm{KGF}$ inhibited $\mathrm{H}_{2} \mathrm{O}_{2}$-induced cleavage of both pro-caspase-3 and the substrate of caspase-3, the PARP protein, in murine lung cells (42).

To further explore the mechanisms through which the protective effect of KGF is achieved in neonates, we used both in vitro and in vivo approaches of the protection of fetal/neonatal rat alveolar epithelial cells against disorders induced by hyperoxia.

\section{METHODS}

ANIMALS. Pregnant Sprague-Dawley rats were purchased from Charles River Laboratories (Saint Germain sur l'Arbresle, France). Animal studies were conducted according to criteria established by INSERM Animal Ethical Committee, and were performed with authorization of the 
French Ministry of Agriculture.

\section{IN VTTRO EXPERIMENTS}

Cell isolation and culture. Alveolar epithelial cells were obtained from enzymatically-dispersed fetal-rat lung cells as previously described (14). Briefly, lungs from 20-day-old fetuses were dissected out under aseptical conditions. Cells were dissociated by incubations in trypsin-collagenase-DNAse in MEM, and then seeded on plastic to allow fibroblasts to adhere for 3 successive 45 min-steps. Finally, 6 differential centrifugations were performed at 120xg for $3 \mathrm{~min}$ to eliminate remnant fibroblasts. Preliminary studies using modified Papanicolaou stain (lamellar body labeling) showed that alveolar type II cell purity of the final cell suspension was $>90 \%$; cell viability (trypan blue exclusion) was $>95 \%$. Isolated alveolar epithelial cells were counted, re-suspended in 10\% FBS-MEM supplemented with penicillin-streptomycin, plated at $4.5 \times 10^{5}$ cells/well in 24 -well polystyrene plates $(1.9 \mathrm{~cm}$ diameter), and allowed to adhere overnight under 95\% air - $5 \% \mathrm{CO}_{2}$. The medium was then replaced for fresh medium (MEM D-Val containing $0.1 \%$ fatty acid-free BSA, thereafter designated simply MEM). Confluent monolayers were formed by $48 \mathrm{~h}$. Plates were placed either under hyperoxic condition $\left(95 \% \mathrm{O}_{2}-5 \% \mathrm{CO}_{2}\right)$ or control condition $\left(95 \%\right.$ air $\left.-5 \% \mathrm{CO}_{2}\right)$ at the time of confluent cell wounding. The following in vitro experiments were repeated 10 times on separate cell isolates, each determination being done in triplicate for each isolate.

Wound Healing Assay. To evaluate the effects of hyperoxia and KGF on the ability of cells to respond to a wound challenge, a linear wound was made with a pipette tip in confluent cell monolayers (30), and cells were washed to remove cell debris. Serum-free MEM containing or not the stimulating molecule (KGF) was added, and cells were placed either under control atmosphere or hyperoxia. Recombinant human KGF (rh-KGF, gift from Amgen, Thousand Oaks, CA, thereafter designated simply KGF) was added at final concentrations 10 and $100 \mathrm{ng} / \mathrm{ml}$. Speed of wound closure by cell migration was evaluated through image analysis system by measurement of the area of the denuded surface immediately after wounding and after $24 \mathrm{~h}$ with aid of an inverted microscope (Zeiss, Thornwood, NY, USA) and a with digital camera (CDD Iris, Sony France, Paris, France). The 
Captured images were subsequently analyzed with image analysis software (National Institutes of Health Image 1.55). The rate of wound repair was expressed as square millimeters per 24 hours.

Cell mortality evaluation. At the end of the procedure, the medium was replaced by trypan-blue dye solution, which incorporates in dead cells. Supernatants were frozen and used for lactate dehydrogenase (LDH) quantification. The assay is based on measurement of LDH released into the medium when the integrity of the cell membrane is lost. Collected media were centrifuged at $120 \mathrm{xg}$ for $7 \mathrm{~min}$ and frozen at $-80^{\circ} \mathrm{C}$ until determinations. Defrozen media were incubated under protection from light for 30 minutes with the substrate mixture in 96-well plates using LDH assay kit based on the reduction of tetrazolium salt INT into formazan (Roche Diagnostics, Meylan, France). Optical density of formazan was read at $490 \mathrm{~nm}$ on a plate reader (Molecular Devices, Saint Grégoire, France).

Cell viability. Cell viability was evaluated using the tetrazolium salt (Sigma-Aldrich, SaintQuentin Fallavier, France) MTT colorimetric assay (34). Briefly, on day 2 of hyperoxia exposure, $62 \mu \mathrm{l}$ of a $0.2 \%$ MTT solution were added to each well containing $0.5 \mathrm{ml}$ of MEM, and the mix was incubated for $2.5 \mathrm{~h}$ at $37^{\circ} \mathrm{C}$ to perform MTT metabolization. The medium was then replaced by $0.5 \mathrm{ml}$ of pure DMSO for $10 \mathrm{~min}$. Then, $200 \mu \mathrm{l}$ of supernatant were recovered and transferred to a $96-w e l l$ plate to measure absorbance at $520 \mathrm{~nm}$.

Evaluation of in vitro cell proliferation by 5-Bromo-2'-Deoxyuridine (Brd-U) labeling. Proliferation was evaluated using the Cell proliferation ELISA Brd-U kit (Roche Diagnostics, Meylan, France). Briefly, cells were seeded in 96 -well plates $(200 \mu 1$ per well of a cell suspension adjusted to $450,000 \mathrm{cells} / \mathrm{ml}$ ), and cultured as usual. On day 2 of culture, cells were labeled with Brd-U for $24 \mathrm{~h}$ while exposed to hyperoxia or air, in the presence or absence of rh-KGF. The DNA was then denaturated by adding Fix Denat solution for $30 \mathrm{~min}$ at $20^{\circ} \mathrm{C}$, then exposed to peroxydase-conjugated anti-BrdU antibody for $90 \mathrm{~min}$. The reaction was stopped and the optical density was determined at $492 \mathrm{~nm}$.

IN VIVO EXPERIMENTS 
Animal treatments. Rat pups born in the laboratory were divided into groups of equal numbers and body weights between each experimental group (i.e., room air or $\mathrm{O}_{2}$ exposure), and kept on a 12:12-h light-dark cycle. Food pellets and water were given ad libitum to the dams.

Litters of randomly divided rat pups and their dams were placed in Plexiglas exposure chambers (Charles River Laboratories) and run in parallel with either $>95 \%$ or $21 \%$ (room air) fraction of inspired oxygen, as previously reported (26) from day 0 to day $10 . \mathrm{O}_{2}$ concentrations were monitored regularly. Because adult rats have limited resistance to high $\mathrm{O}_{2}$, the dams were exchanged daily between $\mathrm{O}_{2}$-exposed and room air-exposed litters. Chambers were opened for $20 \mathrm{~min}$ every day to switch dams treat rat pups, and clean cages. Recombinant human KGF ( $2 \mu \mathrm{g} / \mathrm{g}$ body weight $)$ or vehicle (controls) was injected intraperitoneally at birth and on days 1,3,5 and 7. Lung availability of rhKGF after intraperitoneal injection of $2 \mu \mathrm{g} / \mathrm{g}$ was evaluated preliminary by a specific human kit ELISA (R\&D Systems, Lille, France). Lung concentration was 20 pg/mg lung tissue 6 hours after injection, and decreased to $4 \mathrm{pg} / \mathrm{mg}$ after 24 hours.

On days 5,7 or 10 , rat pups were killed by an intraperitoneal overdose of sodium pentobarbital (70 $\mu \mathrm{g} / \mathrm{g} \mathrm{bw}$ ) and were exsanguinated by aortic transsection. Lungs were either immediately lavaged, or fixed for morphometric/morphologic analysis, or dropped in liquid nitrogen and kept frozen at $80^{\circ} \mathrm{C}$ until further assays.

$B A L$ and cell count in lung fluid. On day 7, rat pups were placed in supine position, and a cannula was inserted in trachea. Isotonic saline was gently instilled with a syringe, then withdrawn. BAL was performed 12 times with $0.33 \mathrm{ml}$ sterile saline, and the 12 lavage samples were pooled. Total cell counts were performed on an aliquot fraction with a hemocytometer, then samples were centrifuged at $300 \mathrm{xg}$ for $7 \mathrm{~min}$. Cell pellets were resuspended in adequate volume to obtain $10^{6}$ cells $/ \mathrm{ml}$, and differential cell counts were performed on cytospin preparations stained with Diff-Quik (Dade Behring, Paris-La Défense, France). A blinded observer counted a minimum of 300 cells to establish the differential cell count. Lavaged lung tissues were discarded.

Lung morphometry analyses. Ten-day-old pups were used. Methods used herein have been 
described in details previously (58). Briefly, lung fixation was performed by tracheal infusion of neutral buffered paraformaldehyde (PFA) at $20 \mathrm{~cm} \mathrm{H}_{2} \mathrm{O}$ pressure, and fixed lung volume was measured by fluid displacement. After routine processing and paraffin embedding, $4 \mu \mathrm{m}$-thick mediofrontal sections through both lungs were stained with hematoxylin-phloxin-saffron (HPS). All morphometric evaluations were made by one single observer (X.D.) who was unaware of group assignment. Volume densities of alveolar airspace, airways, blood vessels larger than $20 \mu \mathrm{m}$ in diameter, and interstitial tissues, and the alveolar surface density were determined using the point counting and mean linear intercept methods (59) at an overall magnification of $\times 440$ using a 42-point, 21-line eyepiece graticle on 20 fields per animal ( 10 per lung) with a systematic sampling method from a random starting point. To correct for shrinkage associated with processing, area values were multiplied by 1.22 as previously calculated. All morphometric data were expressed as relative, absolute, and specific values, as described (13).

Surfactant phospholipid determination. Lipids were extracted from lung tissue homogenates $(5 \mathrm{~d}-$ old pups) or from BAL fluid (7d-old pups) by chloroform : methanol : water 1:2:0,8 ( $\mathrm{vol} / \mathrm{vol} / \mathrm{vol})$. Individual phospholipids were separated by thin layer chromatography, and disaturated phosphatidylcholine (DSPC) was separated by osmium tetroxide and thin layer chromatography, then total phosphatidylcholine (PC), phosphatidylglycerol (PG) and DSPC spots revealed by iodine fixation were scrapped, mineralized, and phosphate was assayed as described previously (8).

Lung DNA content. Lung DNA was determined on the pellet of phospholipid extraction from lung tissue (5d-old pups) by the diphenylamine colorimetric method as described previously (8).

Determination of lung cell proliferation by 5-Bromo-2'-Deoxyuridine labeling (Brd-U). The cell proliferation kit from GE Healthcare (Buckinghamshire, UK) was used. Seven dayold rats were injected intraperitoneally with Brd-U 2 hours before sacrifice. Extracted lungs were fixed through a polyethylene tracheal cannula with OCT embedding medium for frozen tissue specimens (Tissue-Tek, Sakura Finetek Europe B.V., Zoeterwoude, The Netherlands) mixed with PBS, then frozen in liquid nitrogen and stored at $-80^{\circ} \mathrm{C}$. Five-micrometer-thick tissue slices were cut with a cryostat (Jung 
CM3000; Leica Microsystems GmbH, Wetzlar, Germany). Tissue sections were analyzed by immunohistochemistry according to the manufacturer's recommendations: incorporated Brd-U was localized using a specific monoclonal antibody and peroxidase-conjugated antibody to mouse immunoglobulin, polymerising diaminobenzidine (DAB) in the presence of cobalt and nickel (blueblack staining at sites of Brd-U incorporation). Preparations were counterstained with nuclear red. The area of Brd-U positive nuclei was quantified and compared with the total area of nuclei in the same region, labeled by nuclear red using Perfect Image sofware (Clara Vision, Massy, France). A random examination of 10 fields for each right and left lung was performed. Three neonates were included in each condition. Results were expressed as percentage of lung area occupied by Brd-U-positive cells.

Determination of surfactant protein $B(S P-B)$ immunoreactive cells. Immunostaining of postnatal day-10 lung tissue was performed using $5 \mu \mathrm{m}$ paraffin sections that were deparaffinized and rehydrated. Endogenous peroxydase activity was quenched for $30 \mathrm{mn}$ with $3 \% \mathrm{H}_{2} \mathrm{O}_{2}$ in phosphatebuffered saline (PBS). Nonspecific antigenic sites were blocked by incubation with $2 \%$ normal goat serum for 1 hour. Labeling was obtained by incubation with anti-SP-B rabbit polyclonal antibody (gift from J.A.Whitsett, Cincinnati Children's Hospital Medical Center, Cincinnati, Ohio, USA) diluted 1:500, PBS washing, then incubation with horseradish peroxydase-conjugated goat anti-rabbit antibody (Santa Cruz Biotechnology, le Perray, France). Sections were covered with diaminobenzidine tetrahydroxychloride (Vector Laboratories), counterstained with methyl green, dehydrated, and observed with light microscope. As negative control, nonimmune rabbit serum was used. Five samples of 4 fields were counted for each tissue section. Three neonates were included for each condition. Mean total number of cells per field and percentage of SP-B-positive cells are presented.

Determination of the proportion of apoptotic lung cells. The terminal deoxynucleotidyl transferase-mediated dUTP nick-end labeling (TUNEL) assay was used to monitor the extent of DNA fragmentation as a measure of apoptosis in paraffin-embedded sections of lungs from 10d-old pups. The assay was performed with ApopTag Peroxidase in situ Detection Kit according to the recommendations of the manufacturer (Qbiogen, Illkirch, France). Sections were counterstained with methyl green, dehydrated and observed in light 
microscopy. Quantification of TUNEL-positive cells was performed similar to that of BrdU labeling.

Western-blot analysis of caspase 3. Lung tissues collected on days 5 and 10 were homogenized in RIPA buffer containing protease inhibitors cocktail (Roche Molecular Biochemicals, Meylan, France). Homogenates were centrifuged $10 \mathrm{~min}$ at $10,000 \mathrm{xg}$, and protein concentration was determined in supernatants (Bradford assay method). Western blot analysis was performed to evaluate the activated-caspase 3 level in lung homogenates at 5 and 10 days. One hundred $\mu \mathrm{g}$ of proteins were electrophoresed on a $12 \%$ SDS-polyacrylamide gel, and transferred then onto polyvinylidene fluoride membrane (Millipore, Saint-Quentin-en-Yvelines, France); transfer was checked by stain with Ponceau S dye (Sigma, L'Isle-d'Abeau, France) that also served as loading control. Membranes were exposed overnight at $4^{\circ} \mathrm{C}$ to a rabbit anti-caspase 3 antibody (Cell Signaling Technology, Danvers, MA, USA) diluted 1:1000, incubated for $1 \mathrm{~h}$ with horseradish peroxidase-conjugated goat anti-rabbit IgG antibody (Santa Cruz Biotechnology, Santa Cruz, USA) diluted 1:5000, then in Enhanced Chemiluminescence detection reagent (Amersham Bioscience) for $1 \mathrm{~min}$, and finally exposed to Kodak BioMax MS film for 2 min. Densitometry analysis of blots was performed using the VersaDoc Imaging system (BioRad) with the Quantity One program.

RNA extraction and quantitative RT-PCR ( $(P C R)$ analysis. Total RNA was extracted using the guanidinium isothiocynate method (TRIzol reagent, Invitrogen, Cergy-Pontoise, France), followed by purification with Rneasy columns (Qiagen, Courtaboeuf, France). RNAs were reverse-transcribed using $2 \mu \mathrm{g}$ of total RNA, Superscript II reverse transcriptase, and random hexamer primers (Invitrogen) according to the supplier's protocol. Real-time PCR was performed on ABI Prism 7000 device (Applied Biosystems, Courtaboeuf, France) using initial denaturation for $10 \mathrm{~min}$ at $95^{\circ} \mathrm{C}$, and two-step amplification program $\left(15 \mathrm{~s}\right.$ at $95^{\circ} \mathrm{C}$ followed by $1 \mathrm{~min}$ at $\left.60^{\circ} \mathrm{C}\right)$ repeated 40 times. Melt curve analysis was used to check amplification of a single specific product. Reaction mixtures consisted of 25ng cDNA, SYBR Green 2X PCR Master Mix (Applied Biosystems), and forward and reverse primers for the examined transcripts (Table 1) in a reaction volume of $25 \mu 1$. Primers were designed using Primer Express software (Applied Biosystems). Real-time quantification was monitored by 
measuring the increase in fluorescence caused by binding of SYBR Green dye to double-stranded DNA at the end of each amplification cycle. Relative expression was determined using the $\Delta \Delta \mathrm{Ct}$ (threshold cycle) method of normalized samples $(\Delta \mathrm{Ct})$ according to the manufacturer's protocol in relation to the expression of a calibrator sample and of $18 \mathrm{~S}$ rRNA used as a reference. Each PCR run included a no-template control and a sample without reverse transcriptase. All measurements were performed in triplicates.

STATISTICAL ANALYSIS. Data are expressed as means \pm s.e.m. Differences between three or more groups were evaluated using an ANOVA or Kruskal-Wallis test, as appropriate. Differences between two groups were evaluated using Student's $t$ test, Fisher's post hoc test, or Mann-Whitney test, as appropriate and stated in legends. Overall rat-pup survival in relation to treatment was evaluated by Kaplan-Meier survival function, and the log-rank test was used for comparisons between treatment groups. All calculations were performed with Statview software version 5.0 (SAS Institute Inc, Cary, NC). A $p$ value $<0.05$ was considered to be statistically significant.

\section{RESULTS}

IN VITRO EXPERIMENTS

Effects of hyperoxia on wound healing of alveolar type II cell monolayers. Hyperoxia markedly impaired wound healing, decreasing the rate of wound closure by approximately $30 \%$ (Fig. 1A). This impairment was mainly due to cell death, presumably mainly because of necrosis, as observed by numbering of trypan-blue labeled cells that were increased about 8-fold (Fig. 1B). Cell death was confirmed by an increase of LDH release in conditioned medium (Fig. 1C). Cell viability assessed by MTT test was decreased by $40 \%$ under hyperoxia (Fig. 1D) whereas cell proliferation rate was not different (Fig. 1E).

Effects of KGF on alveolar type II cells exposed to hyperoxia. Under control condition $(95 \%$ air $-5 \% \mathrm{CO}_{2}$ ), $\mathrm{KGF}$ alone changed neither the speed of wound healing, nor cell death as evaluated either 
by trypan-blue exclusion or LDH determination, nor cell viability and proliferation (data not shown). Under $95 \% \mathrm{O}_{2}, \mathrm{KGF}$ at the concentration $10 \mathrm{ng} / \mathrm{ml}$ had no effect on all the studied parameters, but when elevated to $100 \mathrm{ng} / \mathrm{ml}, \mathrm{KGF}$ increased the closure speed of the wound about twice $(\mathrm{p}<0.01$, Fig. $2 \mathrm{~A}$ ), and it markedly reduced the dead-cell surface area ( $<<0.001$, Fig. 2B) and slightly decreased the level of LDH released in culture medium ( $p=0.03$ Fig. 2 C). KGF $100 \mathrm{ng} / \mathrm{ml}$ also increased about $75 \%$ cell viability as evaluated by MTT assay ( $\mathrm{p}=0.03$, Fig. $2 \mathrm{D}$ ), but did not change the rate of cell proliferation (Fig. 2E). Interestingly, addition of 5\% FBS to control medium, which increased wound closure rate about 3 times, failed by contrast with KGF to diminish cell-death area extension and LDH release (not shown).

\section{IN VIVO EXPERIMENTS}

Mortality rate. KGF significantly improved the survival of neonates (Fig. 3). On day 10, 14 out of 19 neonates exposed to hyperoxia that had received intraperitoneal KGF were still alive $(73,7 \%)$, whereas only 6 of 18 neonates exposed to hyperoxia that received the vehicle solution only were alive (33,3\%, Log Rank: $p=0.004)$.

Lung morphometry. On day 10, survivors were evaluated for lung morphometry (Table 2). Lung volumes did not differ between subgroups. Hyperoxia significantly altered lung growth. Decreased alveolarization was evidenced by reduced alveolar surface density $(\operatorname{Sv}(a, p) ; p<0.001)$, reduced total alveolar surface (Sa; $p<0.001$ ), reduced interstitial volume density (Vvi; $p<0.001$ ), and increased alveolar airspace volume density (Vva; $p<0.001$ ). Vascular volume density (Vvv) was also significantly reduced by hyperoxia $(p=0.03)$. No change was observed in airspace volume density of airways (VvA). KGF did not attenuate hyperoxia-induced lung development alterations, and decreased $\operatorname{Sv}(a, p)$

Cells in BAL. Cell number and differential count in BAL were determined on day 7, when hyperoxia-induced mortality rate began being significantly different between KGF-treated rat pups and controls. Recovery of instilled saline was similar in all groups. No significant increase in total BAL 
cell count was observed in newborn rats exposed to hyperoxia (Fig. 4). However, the distribution of cells was significantly changed, with a decrease in alveolar macrophage proportion $(p=0.01)$, and a significant neutrophil influx into alveoli $(\mathrm{p}<0.005)$; the latter were extremely rare in basal condition. KGF prevented neutrophil influx $(\mathrm{p}<0.004)$.

Lung DNA content and proportion of SP-B immunoreactive cells. Hyperoxia induced a $40 \%$ decrease in whole-lung DNA content on day 5, which was totally prevented by KGF injections (Fig. 5). To focus on this KGF-induced cell protection in distal lung, we evaluated on lung sections both the total number of nuclei in alveolar walls and the proportion of SP-B-expressing alveolar cells, considered as representing alveolar type II cells. Hyperoxia decreased by about $40 \%$ the total number of cells in alveolar walls in newborns having received the vehicle only ( $p<0.001$, Table 3$)$. This decrease was not observed for SP-B-positive cells, which means that the proportion of SP-B-positive cells was significantly enhanced under hyperoxia. KGF had a significant effect on SP-B-positive cells (Table 2), with both an increase in their absolute number in room air ( $p=0.04$ as compared to vehicleinjected controls) and an increase in their percentage under hyperoxia ( $p<0.001$ as compared to vehicle-injected controls exposed to $\mathrm{O}_{2}$ ).

Lung parenchymal cell proliferation. Brd-U incorporation into lung cells was evaluated at day 7 . The percentage of cells exhibiting Brd-U incorporation was significantly reduced by hyperoxia $(\mathrm{p}<$ 0.002), but was not significantly changed by KGF (Fig. 6). Mean values were $9.6 \pm 1.1,6.4 \pm 1.9,2.7$ \pm 1.2 , and $2.0 \pm 0.5 \%$ of total cells in air-control, air-KGF, hyperoxia-control, and hyperoxia-KGF rat pups, respectively.

Apoptosis. Level of apoptosis evaluated by TUNEL assay was about $1 \%$ of cells in newborns exposed to room air (Table 3). Hyperoxia induced a 2.3 -fold increase in this proportion $(\mathrm{p}<0.05)$. KGF treatment tended to prevent this increase since the value, intermediate between that of controls in air and hyperoxia, was no longer different to that of the former although not significantly different from that of the latter. Caspase 3 was evaluated by semi-quantitative western-blot analysis (Fig. 7). Hyperoxia markedly decreased lung caspase 3 content, which was significantly more pronounced on 
day 10 ( $p<0.005$ between stages). KGF induced a significant decrease in caspase 3 content on day 5 , independently of air or oxygen breathing ( $\mathrm{p}<0.001)$, but not on day 10. The fraction of caspase 3 that was activated significantly increased from day 5 to day 10 in room air neonates $(p<0.03)$. Hyperoxia significantly decreased activated caspase $3(p<0.02)$. No significant difference was associated to KGF treatment.

Surfactant phospholipids. DSPC and PG, the major phospholipids components of surfactant, were determined in whole lung tissue on day 5 (Table 4). Hyperoxia did not significantly change DSPC concentration, whereas it significantly decreased PG concentration by about $25 \%$. KGF treatment had no significant effect on these changes. DSPC was also determined in BAL on day 7 and was found to be increased by hyperoxia; KGF induced changes in the proportion of DSPC neither in room air nor under hyperoxia (Table 4).

Gene expression of EGFR, $T G F \alpha, C / E B P \alpha$ and $V n n 1$. To further explore the possible underlying molecular mechanisms of KGF effects, qPCR was used to quantify the steady state levels of the transcripts of (i) transforming growth factor (TGF) $\alpha$ and its receptor epidermal growth factor receptor (EGFR) previously shown to be involved in the mediation of KGF-enhanced spreading and migration of adult alveolar type II cells (2), and (ii) of the transcription factor CAAT enhancer binding protein $\alpha$ $(\mathrm{C} / \mathrm{EBP} \alpha)$ and the ectoenzyme with pantetheinase activity Vanin 1 (Vnn1) known to be involved in pulmonary cytoprotection during hyperoxia exposure in mice $(40,62)$. These were determined in $5 \mathrm{~d}-$ old rat pups. Hyperoxia increased the transcripts of EGFR and TGF $\alpha$ about 2.3 and 1.8 times, respectively, either in the absence or presence of KGF (Fig. 8). The latter did not change significantly these expression levels, although mean values were slightly higher. $\mathrm{C} / \mathrm{EBP} \alpha$ transcript was not significantly changed by hyperoxia; KGF did not enhance its expression in the lung of pups exposed to room air, but the transcript was by contrast enhanced $88 \%(\mathrm{p}<0.05)$ in animals simultaneously exposed to $\mathrm{O}_{2}$ and $\mathrm{KGF}$ (Fig. 8). The steady state level of $\mathrm{Vnn} 1$ transcript was increased in both $\mathrm{O}_{2}$-vehicle and $\mathrm{O}_{2}-\mathrm{KGF}$ groups as compared to groups in room air, but the increase was statistically significant only for the $\mathrm{O}_{2}-\mathrm{KGF}$ group due to the wide dispersion of individual data in the $\mathrm{O}_{2}$-vehicle group (Fig. 8). 


\section{DISCUSSION}

The present study was undertaken to explore at the cellular level possible mechanisms of KGF action susceptible to account for its protective effects towards the exposure of the developing lung to hyperoxia, used as a model of alveolar injury. We report enhanced rate of alveolar cell wound closure in vitro, and maintenance of lung cell content in vivo, likely to be due to enhanced survival of alveolar epithelial type II cells.

Most of studies demonstrating a protective effect of KGF against lung injury used the intratracheal route $(38,54)$ rather than systemic route $(6)$, whereas we administered KGF intraperitoneally and during oxygen exposure. Possible mechanisms to explain the protective effects of KGF in acute lung injury have been recently reviewed (57) and are mainly based on effects on alveolar and airway epithelial cells, including increased proliferation $(33,39,53,63)$, increased surfactant production $(14,27,50,61)$, enhanced DNA repair $(12,51,60)$, and decreased apoptosis $(12,43)$. These effects were however mainly studied in adult animals or cells, and scarcely examined in the neonatal period.

In this study, we demonstrate the protective effect of exogenous KGF on alveolar epithelial cells in neonatal rats exposed to hyperoxia, but we could not rely this effect to known effects of KGF observed in adult animals, except for the increase of C/EBP $\alpha$ expression. Giving KGF to newborn rats was not significantly associated to increased lung cell proliferation rate, decreased lung cell apoptosis, or increased production of surfactant, but was however shown to have a significant protective effect on alveolar type II cells and to significantly reduce alveolar neutrophil influx. Nevertheless, KGF treatment, although improving type II cell survival, did not prevent disrupted alveolarization, which is in keeping with previous report (22).

Indeed, the present study presents limitations. Changes induced by KGF in cultured cells exposed to hyperxoxia suggest possible protection/repair mechanisms, but do not demonstrate that these mechanisms are effective in vivo, because the cultured epithelial monolayer and the in vitro 
mechanical injury are obviously limited models of the alveolar epithelium and of in vivo injuries, respectively. The in vivo model using $>95 \% \mathrm{O}_{2}$ is extremely severe and might have masked possible effects of KGF susceptible to occur with a milder injury model. This condition was used because it is the one that had previously allowed KGF protection against hyperoxic lethality to be evidenced (22). Lastly, although we explored a number of possible KGF effects, the investigation could not be exhaustive, considering the pleiotrophic effects of this growth factor. For instance, although wet-to-dry lung weight ratio was not changed by KGF in rat neonates (22), anti-edematous effect might have contributed to lung protection because KGF has been reported to enhance sodium and fluid transport and to prevent alveolar edema in a variety of experimental models of lung injury $(3,25,44,56,65)$. Anti-edematous effect could however hardly be explained by maintenance of the type II cell pool, since these cells account for $3-5 \%$ of alveolar surface only, or by restoration of damaged alveolar barrier by transdifferentiation of type II into type I cells, a process that is likely to occur principally during recovery after arrest of hyperoxic exposure. Direct effect of KGF on fluid transport by type I cells, which cover the major part of alveolar surface, appears possible since evidence has been given that type I cells not only reabsorb water, but also contain functional sodium channels and appear responsible for the bulk of transepithelial $\mathrm{Na}^{+}$transport in the lung (28). Last, FGF receptors inhibition has evidenced the key role of the FGF system in regulating vascular integrity (35). KGF might therefore have also prevented fluid leakage and/or favored fluid reabsorption through protection of pulmonary microvascular network. It cannot be ruled out that these mechanisms, together with those reported herein, have contributed to enhanced survival in KGF-treated rat pups exposed to hyperoxia.

DNA determination used to evaluate lung cell number indicated that oxygen damage was associated to cell loss, and that KGF treatment prevented this effect. Oxygen exposure is known to markedly reduce the turnover of alveolar cells. Previous study in adult mice showed no significant restoration by KGF (6). In the present study, KGF was able to prevent oxygen-induced mortality in neonatal rats despite a low lung-cell proliferation rate, arguing for a lung protective effect that is not necessarily associated with its capacity to sustain epithelial cell proliferation since BrdU intake 
increased neither in vivo nor in vitro.

In fact, the main mechanism indicated by our results is the protective effect of KGF towards hyperoxia-induced cell toxicity. Exposure to oxygen is known to result in death of alveolar epithelial and endothelial cells $(7,16)$. It was also suggested that KGF exerted in adult mice a protective effect on epithelial cells (6). Consistently, we report that KGF protected fetal alveolar epithelial cells exposed to hyperoxia in vitro, as evaluated by the extent of cell-death area, by the level of released LDH, and by increased cell viability. In vivo, prevention of lung DNA decrease and elevated percentage of SP-Bpositive cells were also consistent with protection and maintenance of alveolar type II epithelial cells. A reduced number of type II cells was similarly observed previously in neonatal mice recovering from hyperoxia (64), and the KGF-induced increase in type II cell number is consistent with previous findings in adult animals subjected to oleic-acid-induced lung injury (54). KGF overexpression using adenoviral vector was recently shown to induce proliferation of surfactant protein C-positive cuboidal cells, i.e. alveolar type II cells, and also to prevent lung injury (3), which in keeping with present findings. Type II cell preservation is crucial for repair process since alveolar type I cells, which are the most sensitive to injury, reconstitute from type II cells. Higher recovery potential may result from higher percentage of surviving type II cells post injury, which confers therapeutic value to KGF.

A recent investigation showed that the transcription factor $\mathrm{C} / \mathrm{EBP} \alpha$ is required for cytoprotection of type II cells during hyperoxia, and that this effect is likely to be mediated through the transcriptional regulation of the vanin-1 gene (Vnn-l) to trigger a variety of cellular redox-sensitive signaling processes (62). Vanin-1 is a membrane-bound protein with pantetheinase activity that produces cysteamine, a potent anti-oxydant, and indeed, tissues of Vnn1-deficient mice lack cysteamine (40). We therefore hypothesized that cytoprotection of alveolar cells by KGF could be mediated by enhanced $\mathrm{C} / \mathrm{EBP} \alpha$ and/or Vnn1 expression. The transcript level of $\mathrm{C} / \mathrm{EBP} \alpha$ was effectively increased in the lung of rat pups exposed to hyperoxia and treated by KGF as compared with both air-exposed controls and hyperoxia-exposed pups injected with the KGF vehicle. Consistent with the present finding, we had previously evidenced enhanced C/EBP $\beta$ expression by KGF in isolated type II cells 
(5), but $\mathrm{C} / \mathrm{EBP} \alpha$ expression was rapidly lost in vitro, which prevented from determining KGF effects. KGF-increased expression of $\mathrm{C} / \mathrm{EBP} \alpha$, which had not been reported formerly, provides a mechanistic support to type II cytoprotection against hyperoxia, likely to have contributed at least for a part to the decreased mortality of rat pups. By contrast, the $V n n l$ transcript was augmented as a consequence of the sole exposure to hyperoxia, and was not further enhanced by KGF. The effects of enhanced $\mathrm{C} / \mathrm{EBP} \alpha$ could therefore be mediated by the expression control of other genes the product of which are involved in anti-oxidant defense mechanisms. Moreover, the status of Vnn1 appears to be rather complex since Vnn1-deficient mice have been paradoxically reported to exhibit resistance to oxidative injury in spite of the absence of cysteamine, due to elevated stores of glutathione (9).

Despite increased type II cell survival, and although KGF has been reported to enhance the synthesis of surfactant components in vitro $(14,50,61)$ and in vivo $(27)$, we found no effect of KGF on lung surfactant content in hyperoxia-exposed rat neonates. Indeed, the effects of hyperoxia on surfactant synthesis seem to be complex and may have interfered with those of KGF. Thus, the expression of surfactant protein genes is known to be up-regulated by injury including hyperoxia or lipopolysacharide exposure, in adult animals $(37,49)$ as well as in newborns (18). Phospholipid compartment had not been investigated in depth formerly in this condition. Alterations in individual phospholipid components may differ from those of surfactant proteins since we found a decrease in lung tissue PG, but an increase in BAL DSPC. On the other hand, surfactant homeostasis was maintained in rats in vivo following tracheal instillation of KGF despite type II cell hyperplasia (20). Although we did not evaluate the pulmonary content in surfactant proteins in the present study, it seems unlikely that beneficial effects of KGF on survival may relate to surfactant.

We also evaluated in vitro the effect of KGF on wound repair. By contrast with adult type II cells (23), KGF did not enhance wound closure in fetal cells under normoxic condition. Nonetheless, it restored wound closure ability under hyperoxia, which appeared to be due mainly to prevention of cell death. This suggests increased repair potential of type II cells in the presence of KGF. On a mechanistic point of view, previous investigation (2) had evidenced that intratracheal KGF in vivo 
enhanced the repair potential of rat type II cells by nonmitogenic mechanisms through increased spreading and migration, as assessed in vitro on isolated cells. This was shown to require the mediation of TGF $\alpha$ through binding to EGFR (2). We therefore hypothesized that the effects of KGF reported herein could be mediated, at least for a part, by a control of either TGF $\alpha$ or EGFR expression. In fact, the transcripts of both these proteins were markedly elevated by hyperoxic exposure in vivo, consistent in the instance of $\mathrm{TGF} \alpha$ with previous observation in neonatal rabbits (55). KGF, however, induced significant change neither under normoxia nor under hyperoxia. The mechanism evidenced in adult rat cells therefore does not seem to account for the protective effects of KGF in rat neonates.

Cell death resulting from oxygen-induced adult lung injury presents features of both necrosis and apoptosis (7). Our data suggest that nonapoptotic cell death is the predominant effect of hyperoxia in newborns rat lungs as indicated by lack of increase in activated caspase- 3 and by the slight increase in TUNEL-positive cell number. This is also clearly supported by trypan-blue exclusion study in cultured cells, although we did not evaluate apoptosis directly in this instance. Nonapoptotic cell death was previously recorded in cultured human lung epithelium exposed to $\mathrm{O}_{2}$, with swelling of nuclei, increase in cell size, and no evidence for any augmentation in the levels of caspase-3 activity (21). The dissociation we observed between TUNEL and caspase 3 findings is in agreement with the involvement of multiple apoptotic pathways in hyperoxia (7). Thus, in adult mice, despite the evidence of changes specific for apoptosis, including internucleosomal DNA degradation, the marked increase in lung RNA or protein levels of p53, bax, bcl-x, and Fas, which are known to be expressed in certain types of apoptosis, contrasted with the absence of increase in proteases of the apoptosis "executioner" machinery, such as caspase 1 or 3 (7). Furthermore, it has not been possible so far to attenuate oxygeninduced injury by anti-apoptotic strategies (7). In fact, the main inducer of activated caspase 3 in the present study was postnatal age. Apoptosis is known to be involved in lung remodeling during normal pre- and postnatal development in man and rat $(45,46)$. Postnatally, the role of apoptosis appears to be to rid the lung from excess fibroblasts and epithelial cells so as to increase the gas exchange surface area $(31,46)$. Thus, apoptosis levels were shown to abruptly increase at the time of spontaneous birth, 
up to $9 \%$ of cells, and to rapidly decrease then to around $1 \%$ of cells by day 2 of life (31). It remained low during alveolar septation, a stage that is conversely characterized by a high index of proliferation, but from day 13 (i.e. after completed septation), the number of lung fibroblasts undergoing apoptosis increased 4 to 5 -fold (11).

Last, we found that KGF prevented alveolar neutrophil influx in hyperoxia-exposed newborns. A similar effect of KGF was previously shown in adult mice subjected to intratracheal acid instillation, a decrease in MIP- $2 \alpha$ gradients between BAL fluid and plasma being suggested as the underlying mechanism (36). Presumably, cytoprotection of alveolar epithelial cells diminished inflammation signals involved in neutrophil recruitment, including expression of a variety of cytokines. Decreased neutrophil influx might have in turn diminished secondary injury to the epithelium. Moreover, KGF was also shown to decrease ICAM-1 and VCAM-1 expression and neutrophil adherence in bronchial epithelial cells, suggesting its involvement in the resolution of the inflammatory reaction (29).

In conclusion we report evidence for KGF protection of alveolar epithelial cell probably through enhanced anti-oxidant defense mechanisms, enhancing effects on alveolar repair capacity, and antiinflammatory effects in the injured neonatal lung that may account, at least for a part, for the ability of the factor to reduce pup mortality. Although no effects on impaired alveolarization were observed, this argues in favor of a therapeutic potential of KGF in neonatal chronic lung disease.

\section{Acknowledgements}

Recombinant human KGF was kindly gifted by Amgen, Thousand Oaks, CA.

\section{References}

1. Albertine KH, Jones GP, Starcher BC, Bohnsack JF, Davis PL, Cho SC, Carlton DP, Bland 
RD. Chronic lung injury in preterm lambs. Disordered respiratory tract development. Am J Respir Crit Care Med 159: 945-958, 1999.

2. Atabai K, Ishigaki M, Geiser T, Ueki I, Matthay MA, Ware LB. Keratinocyte growth factor can enhance alveolar epithelial repair by nonmitogenic mechanisms. Am J Physiol Lung Cell Mol Physiol 283: L163-169, 2002.

3. Baba Y, Yazawa T, Kanegae Y, Sakamoto S, Saito I, Morimura N, Goto T, Yamada Y, Kurahashi K. Keratinocyte growth factor gene transduction ameliorates acute lung injury and mortality in mice. Hum Gene Ther 18: 130-141, 2007.

4. Baraldi E, Filippone M. Chronic lung disease after premature birth. N Engl J Med 357: 1946-1955, 2007.

5. Barlier-Mur AM, Chailley-Heu B, Pinteur C, Henrion-Caude A, Delacourt C, Bourbon JR. Maturational factors modulate transcription factors CCAAT/enhancer-binding proteins alpha, beta, delta, and peroxisome proliferator-activated receptor-gamma in fetal rat lung epithelial cells. Am J Respir Cell Mol Biol 29: 620-626, 2003.

6. Barazzone C, Donati YR, Rochat AF, Vesin C, Kan CD, Pache JC, Piguet PF. Keratinocyte growth factor protects alveolar epithelium and endothelium from oxygen-induced injury in mice. Am.J Pathol 154: 1479-1487, 1999.

7. Barazzone C, Horowitz S, Donati YR, Rodriguez I, Piguet PF. Oxygen toxicity in mouse lung: pathways to cell death. Am J Respir Cell Mol Biol 19: 573-581, 1998.

8. Benachi A, Jouannic JM, Barlier-Mur AM, Chailley-Heu B, Bourbon JR. Surfactant phospholipids and proteins are increased in fetal sheep with pulmonary hypertension secondary to fetal systemic arteriovenous fistula. Am J Physiol Lung Cell Mol Physiol 288: L562-L568, 2005.

9. Berruyer C, Martin FM, Castellano R, Macone A, Malergue F, Garrido-Urbani S, Millet V, Imbert J, Duprè S, Pitari G, Naquet P, Galland F. Vanin-1-/- mice exhibit a glutathionemediated tissue resistance to oxidative stress. Mol Cell Biol 24: 7214-7224, 2004.

10. Bourbon J, Boucherat O, Chailley-Heu B, Delacourt C. Control mechanisms of lung alveolar 
development and their disorders in bronchopulmonary dysplasia. Pediatr Res 57: 38R-46R, 2005.

11. Bruce MC, Honaker CE, Cross RJ. Lung fibroblasts undergo apoptosis following alveolarization. Am J Respir Cell Mol Biol 20: 228-236, 1999.

12. Buckley S, Barsky L, Driscoll B, Weinberg K, Anderson KD, Warburton D. Apoptosis and DNA damage in type 2 alveolar epithelial cells cultured from hyperoxic rats. Am J Physiol Lung Cell Mol Physiol 274: L714-L720, 1998.

13. Burri, PH, Dbaly J, and Weibel ER. The postnatal growth of the rat lung. I. Morphometry. Anat Rec 178: 711-730, 1974.

14. Chelly N., Mouhieddine-Gueddiche O.-B., Barlier-Mur A.-M., Chailley-Heu B., Bourbon J.R. Keratinocyte growth factor enhances maturation of fetal rat lung type II cells. Am J Respir Cell Mol Biol 20: 423-432, 1999.

15. Chess PR, D'Angio CT, Pryhuber GS, Maniscalco WM. Pathogenesis of bronchopulmonary dysplasia. Semin Perinatol 30:171-178, 2006.

16. Crapo JD, Barry BE, Foscue HA, Shelburne J. Structural and biochemical changes in rat lungs occurring during exposures to lethal and adaptive doses of oxygen. Am Rev Respir Dis 122: 123$143,1980$.

17. Danan C, Franco ML, Jarreau PH, Dassieu G, Chailley-Heu B, Bourbon J, Delacourt C. High concentrations of keratinocyte growth factor in airways of premature infants predicted absence of bronchopulmonary dysplasia. Am J Respir Crit Care Med 165: 1384-1387, 2002.

18. D'Angio CT, Finkelstein JN, Lomonaco MB, Paxhia A, Wright SA, Baggs RB, Notter RH, Ryan RM. Changes in surfactant protein gene expression in a neonatal rabbit model of hyperoxia-induced fibrosis. Am J Physiol Lung Cell Mol Physiol 272: L720L730, 1997.

19. Digeronimo RJ, Mustafa SB, Ryan RM, Sternberg ZZ, Ashton DJ, Seidner SR. Mechanical ventilation down-regulates surfactant protein $\mathrm{A}$ and keratinocyte growth factor expression in premature rabbits. Pediatr Res 62: 277-282, 2007.

20. Fehrenbach A, Bube C, Hohlfeld JM, Stevens P, Tschernig T, Hoymann HG, Krug N, 
Fehrenbach H. Surfactant homeostasis is maintained in vivo during keratinocyte growth factorinduced rat lung type II cell hyperplasia. Am J Respir Crit Care Med 167: 1264-70, 2003.

21. Franek WR, Morrow DM, Zhu H, Vancurova I, Miskolci V, Darley-Usmar K, Simms HH, Mantell LL. NF-kappaB protects lung epithelium against hyperoxiainduced nonapoptotic cell death-oncosis. Free Radic Biol Med 37: 1670-1679, 2004.

22. Frank L. Protective effect of keratinocyte growth factor against lung abnormalities associated with hyperoxia in prematurely born rats. Biol Neonate 83: 263-272, 2003.

23. Galiacy S, Planus E, Lepetit H, Féréol S, Laurent V, Ware L, Isabey D, Matthay M, Harf A, d'Ortho MP. Keratinocyte growth factor promotes cell motility during alveolar epithelial repair in vitro. Exp Cell Res 283: 215-229, 2003.

24. Geiser T, Ishigaki M, van Leer C, Matthay MA, Broaddus VC. $\mathrm{H}_{2} \mathrm{O}_{2}$ inhibits alveolar epithelial wound repair in vitro by induction of apoptosis. Am J Physiol Lung Cell Mol Physiol 287: L448L453, 2004.

25. Guery BP, Mason CM, Dobard EP, Beaucaire G, Summer WR, Nelson S. Keratinocyte growth factor increases transalveolar sodium reabsorption in normal and injured rat lungs. Am J Respir Crit Care Med 155: 1777-1784, 1997.

26. Hosford GE, Olson DM. Effects of hyperoxia on VEGF, its receptors, and HIF-2alpha in the newborn rat lung. Pediatr Res 56: 26-34, 2004.

27. Ikegami M, Jobe AH, Havill AM. Keratinocyte growth factor increases surfactant pool sizes in premature rabbits. Am J Respir Crit Care Med 155: 1155-1158, 1997.

28. Johnson MD, Bao HF, Helms MN, Chen XJ, Tigue Z, Jain L, Dobbs LG, Eaton, DC. Functional ion channels in pulmonary alveolar type I cells support a role for type I cells in lung ion transport. Proc Natl Acad Sci USA 103: 4964-4969, 2006.

29. Just N, Tillie-Leblond I, Guery BP, Fourneau C, Tonnel AB, Gosset P. Keratinocyte growth factor (KGF) decreases ICAM-1 and VCAM-1 cell expression on bronchial epithelial cells. Clin Exp Immunol 132: 61-69, 2003. 
30. Kheradmand F, Folkesson HG, Shum L, Derynk R, Pytela R, Matthay MA. Transforming growth factor-alpha enhances alveolar epithelial cell repair in a new in vitro model. Am J Physiol Lung Cell Mol Physiol 267: L728-L738, 1994.

31. Kresch MJ, Christian C, Wu F, Hussain N. Ontogeny of apoptosis during lung development. Pediatr Res 43: 426-431, 1998.

32. Lu Y, Pan ZZ, Devaux Y, Ray P. p21-activated protein kinase 4 (PAK4) interacts with the keratinocyte growth factor receptor and participates in keratinocyte growth factor mediated inhibition of oxidant-induced cell death. J Biol Chem 278: 10374-10380, 2003.

33. Michelson PH, Tigue M, Panos RJ, Sporn PH. Keratinocyte growth factor stimulates bronchial epithelial cell proliferation in vitro and in vivo. Am J Physiol Lung Cell Mol Physiol 277: L737L742, 1999.

34. Mosmann T. Rapid colorimetric assay for cellular growth and survival: application to proliferation and cytotoxicity assays. J Immunol Methods 65: 55-63, 1983.

35. Murakami M, Nguyen LT, Zhuang ZW, Moodie KL, Carmeliet P, Stan RV, Simons M. The FGF system has a key role in regulating vascular integrity. J Clin Invest 118: 3355-3366, 2008.

36. Nemzek JA, Ebong SJ, Kim J, Bolgos GL, Remick DG. Keratinocyte growth factor pretreatment is associated with decreased macrophage inflammatory protein-2alpha concentrations and reduced neutrophil recruitment in acid aspiration lung injury. Shock 18: 501-506, 2002.

37. Nogee LM, Wispé JR, Clark JC, Weaver TE, Whitsett JA. Increased expression of pulmonary surfactant proteins in oxygen-exposed rats. Am J Respir Cell Mol Biol 4: 102-107, 1991.

38. Panos RJ, Bak PM, Simonet WS, Rubin JS, Smith LJ. Intratracheal instillation of keratinocyte growth factor decreases hyperoxia-induced mortality in rats. J Clin Invest 96: 2026-2033, 1995.

39. Panos RJ, Rubin JS, Csaky KG, Aaraonson SA, Mason RJ. Keratinocyte growth factor and hepatocyte growth factor/scatter factor are heparin-binding growth factors for alveolar type II cells in fibroblast-conditioned medium. JClin Invest 92: 969-977, 1993.

40. Pitari G, Malergue F, Martin F, Philippe JM, Massucci MT, Chabret C, Maras B, Duprè S, 
Naquet P, Galland F. Pantetheinase activity of membrane-bound Vanin-1: lack of free cysteamine in tissues of Vanin-1 deficient mice. FEBS Lett 483: 149-154, 2000.

41. Randell SH, Mercer RR, Young SL. Postnatal growth of pulmonary acini and alveoli in normal and oxygen-exposed rats studied by serial section reconstructions. Am J Anat 186: 55-68, 1989.

42. Ray P. Protection of epithelial cells by keratinocyte growth factor signaling. Proc Am Thorac Soc 2: $221-225,2005$

43. Ray P, Devaux Y, Stolz DB, Yarlagadda M, Watkins SC, Lu Y, Chen L, Yang XF, Ray A. Inducible expression of keratinocyte growth factor (KGF) in mice inhibits lung epithelial cell death induced by hyperoxia. Proc Natl Acad Sci USA 100: 6098-6103, 2003.

44. Sadovski J, Kuchenbuch T, Ruppert C, Fehrenbach A, Hirschburger M, Padberg W, Günther A, Hohlfeld JM, Fehrenbach H, Grau V. Keratinocyte growth factor prevents intraalveolar oedema in experimental lung isografts. Eur Respir J31: 21-28, 2008.

45. Scavo LM, Ertsey R, Chapin CJ, Allen L, Kitterman JA. Apoptosis in the development of rat and human fetal lungs. Am J Respir Cell Mol Biol 18: 21-31,1998.

46. Schittny JC, Djonov V, Fine A, Burri PH. Programmed cell death contributes to postnatal lung development. Am J Respir Cell Mol Biol 18: 786-793, 1998.

47. Shannon JM, Hyatt BA. Epithelial-mesenchymal interactions in the developing lung. Annu Rev Physiol;66: 625-645, 2004.

48. Shannon JM, Pan T, Nielsen LD, Edeen KE, Mason RJ. Lung fibroblasts improve differentiation of rat type II cells in primary culture. Am J Respir Cell Mol Biol 24: 23544, 2001.

49. Sugahara K, Iyama K, Sano K, Kuroki Y, Akino T, Matsumoto M. Overexpression of surfactant protein SP-A, SP-B, and SP-C mRNA in rat lungs with lipopolysaccharide-induced injury. Lab Invest 74: 209-220, 1996.

50. Sugahara K, Rubin JS, Mason RJ, Aronsen EL, Shannon JM. Keratinocyte growth factor increases mRNAs for SP-A and SP-B in adult rat alveolar type II cells in culture. Am J Physiol Lung Cell Mol Physiol 269: L344-L350, 1995. 
51. Takeoka M, Ward WF, Pollack H, Kamp DW, Panos RJ. KGF facilitates repair of radiationinduced DNA damage in alveolar epithelial cells. Am J Physiol Lung Cell Mol Physiol 272: L1174-L1180, 1997.

52. Ueda K, Cho K, Matsuda T, Okajima S, Uchida M, Kobayashi Y, Minakami H, Kobayashi K. A rat model for arrest of alveolarization induced by antenatal endotoxin administration. Pediatr Res 9: 396-400, 2006.

53. Ulich TR, Yi ES, Longmuir K, Yin S, Biltz R, Morris CF, Housley RM, Pierce GF. Keratinocyte growth factor is a growth factor for type II pneumocytes in vivo. J Clin Invest 93: $1298-1306,1994$

54. Ulrich K, Stern M, Goddard ME, Williams J, Zhu J, Dewar A, Painter HA, Jeffery PK, Gill DR, Hyde SC, Geddes DM, Takata M, Alton EW. Keratinocyte growth factor therapy in murine oleic acid-induced acute lung injury. Am J Physiol Lung Cell Mol Physiol 288: L1179L1192, 2005

55. Waheed S, D'Angio CT, Wagner CL, Madtes DK, Finkelstein JN, Paxhia A, Ryan RM. Transforming growth factor alpha (TGF(alpha)) is increased during hyperoxia and fibrosis. Exp Lung Res 28: 361-372, 2002.

56. Wang Y, Folkesson HG, Jayr C, Ware LB, Matthay MA. Alveolar epithelial fluid transport can be simultaneously upregulated by both KGF and beta-agonist therapy. $J$ Appl Physiol 87: 1852$1860,1999$.

57. Ware LB, Matthay MA. Keratinocyte and hepatocyte growth factors in the lung: roles in lung development, inflammation, and repair. Am J Physiol Lung Cell Mol Physiol 282: L924-L940, 2002.

58. Waszak P, Franco-Montoya ML, Jacob MP, Deprez I, Levame M, Lafuma C, Harf A, Delacourt C. Effect of intratracheal adenoviral vector administration on lung development in newborn rats. Hum Gene Ther 13: 1873-1885, 2002.

59. Weibel, ER, and Cruz-Orive LM. Morphometric methods. In: The Lung: Scientific Foundations 
(2nd ed.), edited by Crystal RG, and West JB. Philadelphia, PA: Raven, 1997, p. 333-344.

60. Wu KI, Pollack N, Panos RJ, Sporn PH, Kamp DW. Keratinocyte growth factor promotes alveolar epithelial cell DNA repair after $\mathrm{H}_{2} \mathrm{O}_{2}$ exposure. Am J Physiol Lung Cell Mol Physiol 275: L780-L787, 1998.

61. Xu X, McCormick-Shannon K, Voelker DR, Mason RJ. KGF increases SP-A and SPD mRNA levels and secretion in cultured rat alveolar type II cells. Am J Respir Cell Mol Biol 18: 168-178, 1998.

62. Xu Y, Saegusa C, Schehr A, Grant S, Whitsett JA, Ikegami M. C/EBP \{alpha $\}$ is Required for Pulmonary Cytoprotection During Hyperoxia. Am J Physiol Lung Cell Mol Physiol 297: L286L298, 2009.

63. Yano T, Mason RJ, Pan T, Deterding RR, Nielsen LD, Shannon JM. KGF regulates pulmonary epithelial proliferation and surfactant protein gene expression in adult rat lung. Am J Physiol Lung Cell Mol Physiol 279: L1146-L1158, 2000.

64. Yee M, Vitiello PF, Roper JM, Staversky RJ, Wright TW, McGrath-Morrow SA, Maniscalco WM, Finkelstein JN, O'Reilly MA. Type II epithelial cells are critical target for hyperoxiamediated impairment of postnatal lung development. Am J Physiol Lung Cell Mol Physiol 291: L1101-L1111, 2006.

65. Yi ES, Salgado M, Williams S, Kim SJ, Masliah E, Yin S, Ulich TR. Keratinocyte growth factor decreases pulmonary edema, transforming growth factor-beta and platelet-derived growth factor-BB expression, and alveolar type II cell loss in bleomycin-induced lung injury. Inflammation 22: 315-325, 1998.

66. Yildirim AO, Veith M, Rausch T, Müller B, Kilb P, Van Winkle LS, Fehrenbach H. Keratinocyte growth factor protects against Clara cell injury induced by naphthalene. Eur Respir $J$ 32: 694-704, 2008. 


\section{FIGURE LEGENDS}

Fig. 1. Effects of hyperoxia on cultured alveolar epithelial cells: (A) wound closure rate, (B) cell-death area extension around the wound after $24 \mathrm{~h}$ assessed by trypan blue staining, (C) cell mortality estimated by LDH release in medium, (D) cell viability assessed by MTT test, (E) cell proliferation evaluated by Brd-U incorporation (O.D.: optical density). Cells were cultured in serum-free D-VAL MEM. Control condition was $95 \%$ air $-5 \% \mathrm{CO}_{2}$. Hyperoxia $\left(95 \% \mathrm{O}_{2}-\mathbf{5 \%} \mathrm{CO}_{2}\right)$ decreased the rate of wound closure, increased cell mortality, decreased cell viability, but did not affect cell proliferation. Values are mean \pm s.e.m. of data from 10 separate experiments. Two-group comparisons by Student's $t$ test; significant difference with cells in air- $\mathrm{CO}_{2}$ for: $* * * p<0.001$.

Fig. 2. Effects of $\mathrm{KGF}$ on cultured alveolar epithelial cells maintained under hyperoxia $\left(95 \% \mathrm{O}_{2}-5 \%\right.$ $\mathrm{CO}_{2}$ ): (A) wound closure rate, (B) cell-death area extension assessed by trypan blue staining $(\mathrm{C})$ cell mortality assessed by LDH release in medium, (D) cell viability assessed by MTT test, (E) cell proliferation evaluated by Brd-U incorporation. Results are expressed as percent of mean control value (cells in serum-free D-Val MEM exposed to room air). KGF 10ng/ml had no significant effect whereas KGF $100 \mathrm{ng} / \mathrm{ml}$ increased the rate of wound closure, decreased cell death, and increased cell viability, but had no effect on cell proliferation. Values are mean \pm s.e.m. of data from 10 separate experiments. Multiple comparisons by ANOVA and two-group comparisons by Fisher's post hoc test; significant difference with control for: ${ }^{*} p<0.05,{ }^{* * *} p<0.001$; with hyperoxia for: $+p<0.05,+++p<0.001$.

Fig. 3. Survival rate in newborn rats exposed to hyperoxia from birth to day 10 of age, which received intraperitoneally either KGF (dashed line and squares; $n=19$ ) or vehicle (solid line and circles; $\mathbf{n}=$ 18). KGF markedly reduced the rate of mortality ( $p=0.004$ on day 10$)$. 
Fig. 4. BAL cell contents in 7-day-old rats exposed to room air or hyperoxia from birth. Total cell (grey bars), alveolar macrophage (open bars), and neutrophil (closed bars) counts are presented. Values are mean \pm s.e.m on 6 individuals in each group. Multiple comparisons by Kruskal-Wallis test and two-group comparisons by Mann-Whitney test; significant difference between groups for: **p $<$ 0.01 .

Fig. 5. Whole-lung DNA content determined in 5-day-old rats exposed to room air or hyperoxia from birth. For each condition, newborns received either KGF (grey bars) or vehicle (open bars). Values are mean \pm s.e.m on 6 and 7 individuals per group in room air and hyperoxia, respectively. Multiple comparisons by ANOVA and two-group comparisons by Fisher's post hoc test; significant difference between groups for: ${ }^{* * *} \mathrm{p}<0.001$. Hyperoxia diminished DNA content, i.e. total lung cell number, which was prevented by KGF treatment.

Fig. 6. In vivo BrdU incorporation into alveolar lung cells (black labeling of cell nuclei, arrows): (A) control (room air + vehicle), (B) room air + KGF, (C) Hyperoxia + vehicle, (D) Hyperoxia + KGF. See text for quantitative analysis.

Fig. 7. Lung caspase 3 content evaluated on days 5 and 10 by western-blot. Upper panel: representative blots with $35 \mathrm{kDa}$ band of non activated caspase 3 , and 17 and $19 \mathrm{kDa}$ bands of activated caspase 3; left, 5 days, right 10 days (lanes: vehicle injections in air, KGF injections in air, vehicle injections in $\mathrm{O}_{2}, \mathrm{KGF}$ injections in $\mathrm{O}_{2}$ ); ponceau $\mathrm{S}$ labeling was used as loading control. Lower panel: histogram represents mean values \pm s.e.m. of densitometric analysis of blots $(\mathrm{n}=4$ individuals per group). Open bars: newborns having received the vehicle; grey bars: newborns treated with KGF; lower hatched part of bars: activated fraction of caspase 3. Hyperoxia significantly decreased lung caspase- 3 content. KGF induced a significant decrease in caspase 3 content on day 5 , independently of air or oxygen breathing, but not on day 10 . The activated fraction of caspase 3 significantly increased 
from day 5 to day 10 in room air neonates. Hyperoxia significantly decreased activated caspase- 3 fraction $(p<0.02)$, but no significant restoration was associated to KGF treatment. Multiple comparisons by Kruskal-Wallis test and two-group comparisons by Mann-Whitney test; significant difference with room air for: ${ }^{* * *} p<0.001$; significant difference with vehicle-injected pups for: $\S p<$ 0.001 .

Fig. 8. Steady state level of the transcripts for epidermal growth factor receptor (EGFR), transforming growth factor $\alpha(\mathrm{TGF} \alpha)$, CAAT/enhancer-binding protein $\alpha(\mathrm{C} / \mathrm{EBP} \alpha)$, and Vanin-1 in the lung of 5dold rat pups. Hyperoxia increased EGFR and TGF $\alpha$ transcripts; KGF increased the C/EBP $\alpha$ transcript in the presence of hyperoxia. Multiple comparisons by Kruskal-Wallis test and two-group comparisons by Mann-Whitney test; significant difference with controls in room air for: ${ }^{*} p<0.05$; significant difference with vehicle-injected pups under hyperoxia for: $\S p<0.05$. 
Table 1. Primer sequences for $q P C R$

Genes

Primers $\left(5^{\prime}-3^{\prime}\right)$

Accession \#

EGFR Fw: GGACTGTGTCTCCTGCCAGAA $\quad$ Rv: GGTTCCCCCTCCAGGATGT $\quad$ NM_031507

TGF $\alpha$ Fw: CCCTGGCTGTCCTCATTATCA

Rv: GCACGGCACCACTCACAGT

NM_012671

C/EBP $\alpha$ Fw: TGCGCAAGAGCCGAGATAA

Rv: CGGTCATTGTCACTGGTCAACT

NM_012524

Vnn1 Fw: GGCTATAGGCATGGGAGTCAAT

Rv: AGGCCCGTGGAGAATCG

NM_001025623

Amplicon sizes were 75, 76, 71 and $101 \mathrm{bp}$ for EGFR, TGF $\alpha, \mathrm{C} / \mathrm{EBP} \alpha$ and Vnn1, respectively 
Table 2. Lung morphometry analysis in rat pups treated by rhKGF in room air or under hyperoxia

\begin{tabular}{|c|c|c|c|c|}
\hline & \multicolumn{2}{|c|}{ Room air } & \multicolumn{2}{|c|}{ Hyperoxia } \\
\hline & controls & rhKGF & controls & rhKGF \\
\hline Body weight (g) & $20.6 \pm 0.5$ & $20.1 \pm 0.4$ & $21.1 \pm 0.7$ & $20.8 \pm 1.0$ \\
\hline Lung volume (ml) & $1.05 \pm 0.05$ & $1.05 \pm 0.05$ & $1.10 \pm 0.08$ & $1.00 \pm 0.05$ \\
\hline $\mathrm{Sv}(\mathrm{a}, \mathrm{p})\left(\mathrm{cm}^{2} / \mathrm{cm}^{3}\right)$ & $305 \pm 9$ & $290 \pm 6$ & $220 \pm 19 * * *$ & $189 \pm 4^{* * *} \S$ \\
\hline $\mathrm{Sa}\left(\mathrm{cm}^{2}\right)$ & $263 \pm 18$ & $252 \pm 6$ & $207 \pm 34 * * *$ & $160 \pm 11 * * *$ \\
\hline \multirow[t]{2}{*}{$\operatorname{Vva}\left(\mathrm{cm}^{3} / \mathrm{cm}^{3}\right)$} & $0.658 \pm 0.009$ & $0.664 \pm 0.009$ & $0.739 \pm$ & $0.748 \pm$ \\
\hline & & & $0.019 * * *$ & $0.016 * * *$ \\
\hline \multirow[t]{2}{*}{$\operatorname{Vvi}\left(\mathrm{cm}^{3} / \mathrm{cm}^{3}\right)$} & $0.247 \pm 0.007$ & $0.228 \pm 0.007$ & $0.173 \pm$ & $0.163 \pm$ \\
\hline & & & $0.008 * * *$ & $0.009 * * *$ \\
\hline $\operatorname{Vvv}\left(\mathrm{cm}^{3} / \mathrm{cm}^{3}\right)$ & $0.048 \pm 0.005$ & $0.055 \pm 0.006$ & $0.038 \pm 0.014^{*}$ & $0.035 \pm 0.005^{*}$ \\
\hline $\operatorname{VvA}\left(\mathrm{cm}^{3} / \mathrm{cm}^{3}\right)$ & $0.047 \pm 0.004$ & $0.054 \pm 0.006$ & $0.051 \pm 0.009$ & $0.054 \pm 0.006$ \\
\hline
\end{tabular}

Determinations were made in 10d-old pups; controls received the vehicle of KGF; $n=10$ to 18 for room air/control $; n=10$ to 19 individuals for room air/rhKGF. Sv(a,p), alveolar 
surface density; Sa, total alveolar surface; Vva, alveolar airspace volume density; Vvi, interstitial volume density; Vvv, vascular volume density; VvA, airspace volume density of airways. Multiple comparisons by ANOVA and two-group comparisons by Fisher's post hoc test. Significant difference for: $* p<0.05$ and $* * * p<0.001$ as compared with room aircontrols $; \S \mathrm{p}<0.05$ as compared with hyperoxia-controls 
Table 3. Determination of proportions of SP-B-positive and apoptotic (TUNEL positive) cells in the lungs of rat pups treated by rhKGF in room air or under hyperoxia

\begin{tabular}{|c|c|c|c|c|}
\hline & \multicolumn{2}{|c|}{ Room air } & \multicolumn{2}{|c|}{ Hyperoxia } \\
\hline & controls & rhKGF & controls & rhKGF \\
\hline Total cell count / field & $113 \pm 7$ & $125 \pm 9$ & $71 \pm 4^{* * *}$ & $62 \pm 4 * * *$ \\
\hline SP-B ${ }^{+}$cells / field & $11.6 \pm 1.2$ & $15.3 \pm 1.7^{*}$ & $11.5 \pm 1.2$ & $12.5 \pm 0.8$ \\
\hline$\% \mathrm{SP}^{-\mathrm{B}^{+}}$cells & $10.3 \pm 0.8$ & $12.0 \pm 0.8$ & $16.0 \pm 0.9^{* * *}$ & $20.0 \pm 0.8 * * * \S$ \\
\hline TUNEL $^{+}$cells / field & $1.4 \pm 0.3$ & $1.5 \pm 0.2$ & $2.0 \pm 0.2$ & $1.3 \pm 0.5$ \\
\hline$\%$ TUNEL $^{+}$cells & $1.2 \pm 0.2$ & $1.2 \pm 0.1$ & $2.8 \pm 0.3^{*}$ & $2.1 \pm 0.8$ \\
\hline
\end{tabular}

Determinations were made in 10d-old pups; controls received the vehicle of KGF; $n=3$ per experimental group. Multiple comparisons by Kruskal Wallis test and two-group comparisons by Mann Whitney test. Significant difference for: $* p<0.05$ and $* * * p<0.001$ as compared with room air-controls ; $\S p<0.001$ as compared with hyperoxia-controls. 
Table 4. Surfactant phospholipids in rat pups treated by rhKGF in room air or under hyperoxia

\begin{tabular}{|c|c|c|c|c|}
\hline & \multicolumn{2}{|c|}{ Room air } & \multicolumn{2}{|c|}{ Hyperoxia } \\
\hline & controls & rhKGF & controls & rhKGF \\
\hline \multicolumn{5}{|l|}{ Lung-tissue phospholipids } \\
\hline DSPC (nmol/mg prot.) & $45.3 \pm 2.0$ & $40.7 \pm 0.5^{\S}$ & $53.3 \pm 5.4$ & $42.2 \pm 3.6$ \\
\hline PG (nmol/mg prot.) & $11.2 \pm 0.7$ & $9.9 \pm 0.4$ & $7.2 \pm 0.8^{* *}$ & $7.1 \pm 0.3^{* *}$ \\
\hline \multicolumn{5}{|l|}{ Lung-lavage phospholipids } \\
\hline TPL (nmol/ml) & $31.3 \pm 3.1$ & $21.0 \pm 1.4^{*}$ & $35.2 \pm 0.1$ & $31.1 \pm 2.5$ \\
\hline DSPC (nmol/ml) & $19.0 \pm 1.8$ & $13.8 \pm 0.8^{*}$ & $24.6 \pm 1.2^{*}$ & $22.3 \pm 1.1$ \\
\hline DSPC/TPL (\%) & $60.6 \pm 1.0$ & $65.6 \pm 2.1$ & $75.7 \pm 3.6^{*}$ & $71.7 \pm 3.1^{*}$ \\
\hline
\end{tabular}

Determinations were made in $5 \mathrm{~d}$-old pups for tissue phospholipids $(\mathrm{n}=6$ or 7$)$ and in $7 \mathrm{~d}$-old pups for lung-lavage phospholipids ( $n=4$ or 5); controls received the vehicle of rhKGF. DSPC: disaturated phosphatidylcholine; PG: phosphatidylglycerol; TPL: total phospholipids. Multiple comparisons by ANOVA and two-group comparisons by Fisher's post hoc test. 
Significant difference for: ${ }^{*} p<0.05$ and ${ }^{*} p<<0.01$ as compared with room air-controls; $\S_{\mathrm{p}}<0.05$ as compared with hyperoxia-controls. In lung tissue, only PG was changed by hyperoxia, and this was unaffected by KGF. The proportion of DSPC (DSPC/TPL) in lung lavage fluid was increased by hyperoxia, but unchanged by KGF. 
